\title{
ANALISIS REAKSI PASAR ATAS KEBIJAKAN TAX AMNESTY: STUDI PADA BURSA EFEK INDONESIA
}

\author{
B. Anggun Hilendri L \\ Eni Indriani \\ Retno Dwi H
}

\begin{abstract}
Economic events frequently determine stock price fluctuations in stock exchanges. Sometimes, these economic events tend to get negative responses from market participants. This study uses event study analysis, where the event analyzed was the announcement of government policy in the fiscal sector, the tax amnesty. The announcement of the tax amnesty policy implementation is considered to provide information that elicits reaction in the capital market, which can be measured by the abnormal return on the stock before and after the announcement of tax amnesty policy. This event window of this study was 6 trading days i.e. $t-3$ to $t+3$ since tax amnesty policy became published on July 14, 2016. The sample used in this study consisted of 45 companies listed in LQ-45 index during July 2016. Analysis of average abnormal return is performed based on paired sample $t$-test on three days before and three days after the announcement of tax amnesty policy. The test results show that there is a significant difference in market reaction as indicated by abnormal return value. However, the result of abnormal return shows negative value. It means that tax amnesty policy provides negative information for investor, which is contrary to the objective of tax amnesty policy to increase investment.
\end{abstract}

Keywords: tax amnesty, market reaction, abnormal return, event study

\section{PENDAHULUAN}

\section{Latar Belakang}

Pemerintah mempunyai peran sebagai pengatur alokasi sumber daya, peran regulator, peran kesejahteraan sosial dan peran pengelola ekonomi makro (Sasana,2004). Indikasi dari berhasilnya pemerintah dalam menjalankan perannya adalah peningkatan lapangan pekerjaan, investasi semakin tinggi, ekonomi biaya rendah, seluruhnya bermuara pada kemerataan dan peningkatan kesejahteraan masyarakat

Pemerintah dalam menerapkan suatu kebijakan, seyogyanya menerapkan proses yang mendalam, termasuk didalamnya adalah melakukan 
evaluasi jika kebijakan publik telah diterapkan. Aspek-aspek yang perlu diperhatikan adalah dampak kebijakan yang diharapkan (intended consequences) atau yang tidak diharapkan (unintended consequences) baik pada problemnya maupun pada masyarakat (Islamy,2001:115). Dalam bidang ekonomi, kebijakan pemerintah terdiri atas dua sektor, yaitu sektor moneter dan fiskal. Salah satu bentuk kebijakan fiskal adalah kebijakan pajak, yang cukup populer saat ini adalah tax amnesty. Kebijakan pajak bukan hanya menetapkan tarif dan jenis pajak, tetapi juga dapat dalam bentuk pengampunan pajak (tax amnesty).

Tax amnesty oleh pemerintah digolongkan sebagai bentuk insentif pajak, karena konteksnya adalah pengampunan pajak yang berdampak pada pembayaran pajak yang lebih rendah oleh wajib pajak. Tax amnesty (pengampunan pajak) merupakan konsep penghapusan sanksi yang diberikan oleh presiden dalam keadaan atau situasi tertentu kepada wajib pajak yang telah melakukan pelanggaran terhadap undang-undang perpajakan (Muttaqin,2013:30).

Aspek yang mendasari pemerintah Indonesia menerapkan tax amnesty bukan sebatas keperluan pendapatan negara yang semakin besar. Fakta empiris pendapatan nasional Indonesia pada periode 2010-2016 mengalami pertumbuhan $14,07 \%$, begitu juga dengan kontribusi dari sektor pajak, bahkan pada tahun 2016 merupakan kontribusi tertinggi, sebesar 74,63\% (Direktorat Jenderal Anggaran, 2016).

Secara empiris, kebijakan tax amnesty merupakan pilihan kebijakan sektor fiskal yang seolah berulang, jika ada resesi dunia. Indonesia pernah melakukan kebijakan tax amnesty pada tahun 1964 (melalui Penetapan Presiden No. 5 Tahun 1964 tentang Peraturan Pengampunan Pajak) dan 1984 (melalui Keputusan Presiden Republik Indonesia Tahun 1984 tentang Pengampunan Pajak) serta tahun 2008 dalam bentuk sunset policy.

Dana yang diperoleh dari kebijakan tax amnesty menjadi sumber pembiayaan pembangunan yang diharapkan mampu menggerakkan perekonomian nasional. Secara spesifik dana repatriasi diatur dalam undangundang agar diarahkan pada investasi di pasar modal melalui investasi a) surat berharga Negara Republik Indonesia, b) obligasi Badan Usaha Milik Negara, c) obligasi lembaga pembiayaan yang dimiliki oleh Pemerintah, d) investasi keuangan pada Bank Persepsi, e) obligasi perusahaan swasta yang perdagangannya diawasi oleh Otoritas Jasa Keuangan, f) investasi infrastruktur melalui kerja sama Pemerintah dengan badan usaha, g) investasi sektor riil berdasarkan prioritas yang ditentukan oleh Pemerintah; dan/atau h) bentuk investasi lainnya yang sah sesuai dengan ketentuan peraturan perundang-undangan (Direktorat Jenderal Pajak, 2017). 
Implementasi dari dana yang diperoleh dari tax amnesty harus dirasakan oleh masyarakat luas, salah satunya adalah bergeraknya perekonomian melalui investasi langsung pada pembangunan ataupun investasi portofolio di pasar modal

IHSG merupakan cermin dari gabungan pertumbuhan saham-saham perusahaan yang listed di pasar modal, jika perekonomian semakin baik, maka harga saham akan mengalami peningkatan dan memberikan indikasi capital gain pada setiap pemegang saham. IHSG muncul sebagai ekspektasi return, dijadikan pembanding dalam perolehan return aktual atas saham yang dimiliki. Proses pembandingan antara return aktual dengan return ekspektasi merupakan indikator reaksi pasar, dikenal dengan abnormal return (Fahmi,2014:510). Abnormal return (return tak normal/excess return) adalah kelebihan dari return yang sesungguhnya terjadi terhadap return normal (Hartono,2016:647). Dijelaskan lebih lanjut bahwa return normal merupakan return ekspektasi, berarti return tak normal merupakan selisih return sesungguhnya dengan return perkiraan. Return itu sendiri adalah harga sekarang relatif terhadap harga sebelumnya (capital gain). Berdasarkan makna tersebut, maka para investor mengharapkan return tak normal bernilai positif. Pernyataan lainnya adalah return tak normal positif atas suatu peristiwa menunjukkan berita atau stimulan baik, sedangkan return tak normal negatif menunjukkan suatu peristiwa dengan kabar buruk atau stimulan negatif terhadap perekonomian.

Terkait riset Ngadiman dan Huslin (2015) menemukan bahwa kebijakan tax amnesty berpengaruh signifikan terhadap kepatuhan wajib pajak. Artinya wajib pajak (perusahaan) mempunyai tanggapan positif atas kebijakan tax amnesty, karena memberikan kemudahan dan dapat menikmati implikasi dana pembangunan dari pemerintah. Hal ini dibuktikan juga oleh penelitian Gunawan (2016) bahwa tax amnesty secara nyata meningkatkan penerimaan negara.

Berdasarkan fenomena yang terjadi peneliti tertarik untuk mengangkat judul tentang "Analisis Reaksi Pasar Atas Kebijakan Tax Amnesty : Studi Pada Bursa Efek Indonesia dimana peneliti akan melakukan penelitian lebih lanjut atas implikasi kebijakan tax amnesty, yang seharusnya mampu menggerakkan perekonomian nasional Indonesia untuk nantinya dapat meningkatkan nilai investasi, dimana penelitian ini fokus pada saham perusahaan-perusahaan terbaik yang ada di pasar modal (BEI).

\section{Perumusan Masalah}

Pemerintah Indonesia pada tanggal 14 Juli 2016 secara efektif memberlakukan tax amnesty, di mana dalam perundang-undangan ditujukan 
Bq. Anggun HL, Eni Indriani, \& Retno Dwi H.: Analisis Reaksi Pasar atas...

untuk menggerakkan investasi. Berdasarkan hal tersebut, maka rumusan masalah dalam penelitan ini adalah :

"Apakah terdapat perbedaan yang signifikan atas reaksi pasar (abnormal return) pada perusahaan LQ-45 yang terdaftar di BEI sebelum dan sesudah tax amnesty 14 Juli 2016"?

\section{Tujuan Penelitian}

Adapun tujuan dari penelitian ini adalah untuk Mengetahui perbedaan yang signifikan atas reaksi pasar (abnormal return) pada perusahaan LQ-45 yang terdaftar di BEI sebelum dan sesudah tax amnesty 14 Juli 2016".

\section{Manfaat Penelitian}

Penelitian ini diharapkan dapat menambah pengetahuan terkait dengan reaksi pasar modal atas adanya suatu peristiwa yang dapat digunakan sebagai bahan pertimbangan penetapan keputusan yang berkaitan dengan harga saham, dan menambah pengetahuan tentang dua teori investasi yang sifatnya berlawanan dalam analisis saham yaitu analisis teknikal dan fundamental. Disamping itu, hasil penelitian ini dapat menjadi salah satu masukan bagi pemerintah dalam menerapkan kebijakan, secara khusus kebijakan tax amnesty dan menjadi referensi peneliti selanjutnya dengan topik yang sama.

\section{TINJAUAN PUSTAKA}

\section{Landasan Teori}

\section{Teori Sinyal (Signaling Theory)}

Signaling theory adalah teori yang membahas tentang naik turunnya harga dipasar seperti harga saham, obligasi dan sebagainya (Fahmi,2014:21). Teori ini menyatakan bahwa manajer lebih tahu mengenai informasi yang ada pada perusahaan, faktor-faktor yang mempengaruhi dengan intensitas yang tinggi dibandingkan dengan pihak luar perusahaan. Berhubungan dengan adanya tax amnesty, jika perusahaan mengikuti atau tidak mengikutinya, maka perlu disampaikan yang sebenarnya, termasuk implikasinya atas kondisi keuangan perusahaan.

\section{Teori Stakeholder (Stakeholder Theory)}

Teori Stakeholder merupakan teori yang menyatakan bahwa perusahaan bukanlah entitas yang hanya beroperasi untuk kepentingan sendiri, namun harus memberikan manfaat kepada seluruh stakeholder-nya antara lain pemegang saham, kreditor, konsumen, supplier, pemerintah, 
masyarakat, analis, dan pihak lain (Ghozali dan Chariri,2007) dalam Iryanie (2009). Dengan adanya kebijakan pemerintah tentang Tax Amnesty yang dimana dalam teori ini pemerintah dan pemegang saham dianggap sebagai stakeholder inilah yang menjadi bahan pertimbangan bagi manajemen perusahaan dalam mengungkap atau tidak suatu informasi di dalam laporan perusahaan tersebut.

\section{Landasan Konsep Pasar Modal}

Pasar secara umum sebagai tempat pertemuan perilaku konsumen dan pembeli. Pasar dalam penelitian ini fokus pada produk berupa surat-surat berharga (portofolio), sehingga spesifik pasar yang dimaksud adalah pasar modal. Definisi pasar modal (bursa efek) dalam perundangan sebagai "pihak yang menyelenggarakan dan menyediakan sistem dan atau sarana untuk mempertemukan panawaran jual dan beli efek pihak-pihak lain dengan tujuan memperdagangkan efek di antara mereka" (ayat 4 pasal 1 UU No. 8 Tahun 1995 tentang Pasar Modal). Sistem dan atau sarana meliputi aspek yang luas yang menyebabkan penawaran, pembelian dan aspek lain termasuk prosedur pendaftaran perusahaan yang akan menjual sahamnya mendapatkan pengaturan yang optimal, sehingga tidak ada pihak yang dirugikan.

Definisi sederhana mengenai pasar modal juga diberikan oleh Siegel dan Shim dalam Fahmi (2014:305), yaitu "pusat perdagangan utang jangka panjang dan saham perusahaan". Pengertian yang sama diberikan oleh Shook dalam Fahmi,(2014:305) sebagai sebuah pasar tempat dana-dana modal, seperti ekuitas dan hutang diperdagangkan. Pasar modal diharapkan menjadi alternatif perolehan modal bagi perusahaan yang membutuhkan modal dan sisi lain bagi lenders mengharapkannya sebagai sumber perolehan pendapatan, baik dari bunga, capital gain dan EPS (earning per share).

Tingginya transaksi di pasar modal pada prinsipnya mempunyai makna yang sama dengan tingginya transaksi pada sektor perbankan dan sektor riil, menunjukkan bahwa kondisi ekonomi baik. Hartono (2016:84) mengidentifikasi perkembangan bursa efek menjadi lima belas periode, dengan berbagai indikasi kondisi pasar. Kondisi pasar tersebut digambarkan dengan perkembangan Indeks Harga Saham Gabungan (IHSG). Dalam perjalanannya IHSG dijadikan sebagai salah satu piranti perekonomian (dengan tahun dasar 10 Agustus 1982), di mana peningkatannya pada setiap periode memberikan indikasi bahwa perekonomian makro mengalami perbaikan. Dalam analisis para investor, IHSG dijadikan sebagai return 
ekspektasi untuk mengukur return yang diperoleh pada saham yang akan dipilih ataupun dipertahankan.

Kaitan informasi di pasar modal dikenal dengan istilah efisiensi pasar. Makna efisiensi pada pasar modal, tidak terkait perbandingan antara output dan input atau minimalisasi penggunaan input atau maksimalisasi hasil pada setiap penggunaan input tertentu. Hanafi dan Halim (2005:315) menyatakan bahwa efisiensi pasar terkait dengan "harga-harga surat berharga mencerminkan semua informasi yang tersedia. Semakin efisien suatu pasar modal akan semakin cepat penyebaran informasi tersebut pada pelaku pasar". Kajian pertama mengenai efisiensi pasar dilakukan oleh ahli statistik "Maurice Kendall" (Hanafi dan Halim, 2005:315) yang memperhatikan harga saham yang sangat acak, tidak membentuk pola tertentu. pertanyaan penting yang dirumuskan adalah apakah kondisi tersebut menunjukkan kondisi pasar yang rasional, setelah dilakukan perhitungan dan kajian mendalam, ternyata pola acak tersebut menunjukkan pasar yang rasional. Harga saham yang random tersebut menunjukkan informasi-informasi yang relevan. Setiap adanya informasi akan memberikan dampak pada perubahan harga saham/sekuritas.

\section{Pajak}

Pajak dalam implementasinya harus didasarkan atas undang-udang. Hal ini dilihat dari berbagai definisi mengenai pajak. Pajak adalah "kontribusi wajib pada negara yang terhutang oleh orang pribadi atau badan yang bersifat memaksa berdasarkan undang-undang, dengan tidak mendapatkan imbalan langsung dan digunakan untuk keperluan negara bagi sebesarbesarnya kemakmuran rakyat" (pasal 1 UU No. 16 Tahun 2009 tentang Ketentuan Umum dan Tata Cara Perpajakan).

Pajak dapat bersifat dipaksakan, ditegaskan dalam definisi yang diberikan oleh Soemitro (1990:5) dalam waluyo (2014:3), yaitu "iuran kepada kas negara berdasarkan undang-undang (yang dapat dipaksakan) dengan tidak mendapat jasa timbal balik (kontraprestasi), yang dapat langsung ditunjukkan dan digunakan untuk membayar pengeluaran umum". Pengeluaran umum tersebut untuk menciptakan kesejahteraan umum, sesuai dengan definisi yang diberikan Soeparman dalam Waluyo (2014:3), yaitu "iuran wajib berupa uang atau barang yang dipungut oleh penguasa berdasarkan norma-norma hukum, guna menutup biaya produksi barangbarang dan jasa-jasa kolektif dalam mencapai kesejahteraan rakyat. Fungsi pengaturan dari pajak, yaitu untuk mengatur aspek sosial dan ekonomi (Waluyo, 2014:6). Misalnya aspek sosial, terkait minuman keras ditetapkan pajak barang beralkohol dengan tarif yang tinggi. Dapat juga digunakan 
untuk memproteksi pebisnis dalam negeri dari serbuan barang impor, dengan cara menetapkan pajak impor atau bea masuk yang tinggi.

Pajak bersifat memaksa, tetapi bukan berarti dijalankan dengan semena-mena, baik dalam proses penetapannya atau dalam pelaksanaannya. Hal ini ditegaskan dalam asas-asas pemungutan pajak (Waluyo, 2014:13), sebagai berikut:

a. Equality: pemungutan pajak harus bersifat adil dan merata. Pajak yang dikenakan kepada orang pribadi harus sebanding dengan kemampuan membayar pajak (ability to pay) dan sesuai dengan manfaat yang diterima.

b. Certainty: penetapan pajak tidak boleh sewenang-wenang. Wajib pajak harus mengetahui secara jelas dan pasti besarnya pajak yang terhutang, waktu pembayaran dan batas waktu pembayaran.

c. Convenience: pembayaran pajak dilakukan saat-saat yang tidak menyulitkan wajib pajak (pay as you earn).

d. Economy: biaya pemungutan dan pemenuhan kewajiban pajak bagi wajib pajak diharapkan seminimun mungkin.

\section{Tax Amnesty}

Salah satu kebijakan pajak yang diterapkan pada tahun terakhir ini oleh pemerintah Indonesia adalah tax amnesty. Sesuai dengan namanya tax amnesty (pengampunan pajak), maka berlandaskan dari makna amnesti yang diterapkan dalam pajak. Pihak yang berwenang memberikan amnesti hanya presiden, sesuai dengan ketentuan UU No. 27 Tahun 2003 yang berlandaskan Ketetapan MPR No. XXVI Tahun 2000 tentang Pemantapan Persatuan dan Kesatuan Nasional.

Amnesti bukan suatu yang berlangsung dalam kondisi biasa (ordinary), sehingga dalam penerapannya harus pada moment tertentu. Selanjutnya diberikan pengertian tax amnesty sebagai "pemberian fasilitas perpajakan berupa pembebasan dalam periode atau tenggang waktu tertentu dari pengenaan, pemeriksaan, pengusutan dan penuntutan atas harta kekayaan atau penghasilan yang sebelumnya tidak atau belum sepenuhnya dikenakan pajak yang dilandasi oleh adanya pengakuan kesalahan dari wajib pajak dengan menyesali kesalahan tersebut dan janji tidak akan mengulangi kesalahan" (Muttaqin, 2013:30). Tax amnesty tahun 2016 ditetapkan dengan tujuan:

a. Mempercepat pertumbuhan dan restrukturisasi ekonomi melalui pengalihan harta, yang antara lain berdampak pada peningkatan likuiditas domestik, perbaikan nilai tukar rupiah, penurunan suku bunga dan peningkatan investasi. 
Bq. Anggun HL, Eni Indriani, \& Retno Dwi H.: Analisis Reaksi Pasar atas...

b. Mendorong reformasi perpajakan menuju sistem perpajakan yang lebih berkeadilan serta peluasan basis data perpajakan yang lebih valid, komprehensif dan terintegrasi.

c. Meningkatkan penerimaan pajak, yang antara lain akan digunakan untuk pembiayaan pembangunan (pasal 2 ayat 2 UU No 11 Tahun 2016).

Tax amnesty dalam penelitian ini fokus pada implementasi UU No. 11 Tahun 2016. Adanya tindakan wajib pajak dalam pengungkapan harta, maka dipastikan ada perubahan neraca perusahaan. Dalam UU No. 11 Tahun 2016 diperlakukan sebagai saldo laba ditahan. Harta yang dimaksud bukan saja harta berupa tanah, tetapi juga termasuk berupa saham.

\section{Reaksi Pasar}

Reaksi pasar atas suatu peristiwa (ekonomi, politik, keamanan, bencana alam dan kejadian lain) biasanya menggunakan analisis return tak normal (abnormal return). Didefinisikan sebagai selisih dari return aktual dengan return ekspektasi (Hartono, 2016:647). Secara matematis dirumuskan oleh Hartono (2016:648), sebagai berikut:

$$
\mathrm{RTN}_{\mathrm{i} . \mathrm{t}}=\mathrm{R}_{\mathrm{i} . \mathrm{t}}-\mathrm{E}\left[\mathrm{R}_{\mathrm{i} . \mathrm{t}}\right]
$$

Keterangan:

$\mathrm{RTN}_{\mathrm{i} . \mathrm{t}}=$ Return tak normal sekuritas ke-i pada periode peristiwa ke-t.

$\mathrm{R}_{\mathrm{i} . \mathrm{t}} \quad=$ Return realisasian yang terjadi untuk sekuritas ke-i pada

$$
\text { Peristiwa ke-t }=\frac{\left(\mathrm{P}_{\mathrm{i} . \mathrm{t}}-\mathrm{P}_{\mathrm{i}(\mathrm{t}-1)}\right)}{\mathrm{P}_{\mathrm{i}(\mathrm{t}-1)}}
$$

$\mathrm{E}\left[\mathrm{R}_{\mathrm{i} . \mathrm{t}}\right]=$ Return ekspektasi sekuritas ke-i untuk periode peristiwa ke-t.

Perhitungan return ekspektasi oleh Warner (1985) dalam Hartono (2016:648), terdiri atas model estimasi mean-adjusted model, market model dan market-adjusted model. Berikut uraiannya:

a. Mean adjusted model (model sesuaian rata-rata) mempunyai asumsi bahwa return ekspektasian bernilai konstan yang sama dengan rata-rata return realisasi sebelumnya selama periode estimasi, sebagai berikut (Hartono, 2016:648):

$$
E\left[R_{i . t}\right]=\frac{\sum_{j=t 1}^{12} R_{i . j}}{T}
$$

Keterangan:

$E\left[R_{i, t}\right]=$ Return ekspektasian sekuritas ke-i pada periode peristiwa ke- $t$.

$R_{i j} \quad=$ Retrun realisasian sekuritas ke-i pada periode estimasi ke-j.

$\mathrm{T} \quad=$ Lamanya periode estimasi, yaitu dari $\mathrm{t} 1$ sampai dengan 12 . 
Periode estimasi umumnya merupakan periode sebelum periode peristiwa. Periode peristiwa (event period) disebut juga dengan periode pengamatan atau jendela peristiwa (event window). Periode jendela sebagai periode pengamatan merpakan periode yang akan dihitung nilai abnormal return-nya.

b. Market model dilakukan dengan dua tahap, yaitu 1) membentuk model ekspektasi dengan menggunakan data realisasi selama periode estimasi dan 2) menggunakan model ekspektasi ini untuk mengestimasi return ekspektasian di periode jendela. Model ekspektasi dapat menggunakan analisis regresi dengan metode OLS (ordinary least square), sebagai berikut (Hartono, 2016:653):

Keterangan:

$$
R_{i j}=\alpha_{i}+\beta_{i} \cdot R_{M j}+\varepsilon_{i . j}
$$

$\mathrm{R}_{\mathrm{ij}}=$ Return realisasian sekuritas ke-i pada periode estimasi ke-j.

$\alpha_{i}=$ Intercept untuk sekuritas ke-i

$\beta_{\mathrm{i}}=$ Koefisien slope yang merupakan beta dari sekuritas ke-i

$\mathrm{R}_{\mathrm{Mj}}=$ Return indeks pasar pada periode estimasi ke-j

$$
=\frac{\left(\mathrm{IHSG}_{\mathrm{j}}-\mathrm{IHSG}_{(\mathrm{j}-1)}\right)}{\mathrm{IHSG}_{\mathrm{j}-1}}
$$

Market model dapat dikerjakan dengan menggunakan analisis regresi linear sederhana, di mana setiap sekuritas mempunyai model atau persamaan sendiri. Model tersebut dibentuk dengan periode estimasi, selanjutnya dijadikan dasar dalam menentukan return pada setiap saham. Perhitungan abnormal return tetap menggunakan selisih dari return aktual dengan return ekspektasi.

c. Market adjusted mode/; model ini mempunyai asumsi bahwa penduga terbaik untuk mengestimasi return suatu sekuritas adalah return indeks pasar pada saat tersebut. Dengan menggunakan model ini tidak diperlukan periode estimasi untuk membentuk model estimasi. Return yang diestimasi adalah return indeks pasar. Model ini yang selanjutnya digunakan oleh peneliti $\left(R T N_{i . t}=R_{i . t}-E\left[R_{i . t}\right]\right)$, di mana dilakukan perhitungan untuk setiap saham pada periode jendela, selanjutnya dilakukan uji beda atas dua periode pra dan pasca peristiwa terkait.

\section{Kerangka Konseptual dan Pengembangan Hipotesis Kerangka Konseptual}

Tax amnesty sebagai suatu kebijakan fiskal telah dipraktekkan di beberapa negara, ada yang berhasil dan ada yang gagal. Kegagalan menunjukkan bahwa negara tidak mampu membentuk kepatuhan wajib 
pajak, diindikasikan dengan kecilnya dana tebusan atas harta yang belum atau tidak lengkap dilaporkan oleh wajib pajak. Nar (2015) mengidentifikasi perilaku atas tax amnesty, bahwa pelaku ekonomi selalu bersifat rasional dengan meminimalkan pengeluaran, sehingga berperilaku menolak tax amnesty. Pajak diindikasikan sebagai biaya saat ini, karena harus membayar cash dana tebusan, menghilangkan keberatan lebih bayar pada pemerintah melalui Dirjen Pajak dan implikasi lanjutannya, bahwa harta yang dimunculkan akan menjadi penambah saldo laba ditahan dan berimplikasi pada peningkatan laba. Rahayu (2016) dalam penelitiannya juga membuktikan bahwa reaksi pasar tidak berbeda nyata antara periode sebelum dan sesudah adanya kebijakan tax amnesty.

Abnormal return secara langsung dapat dihitung untuk setiap perusahaan pada setiap periode kajian (sebelum dan sesudah kebijakan tax amnesty). Guna lebih jelasnya dirumuskan dalam kerangka konseptual sebagai berikut:

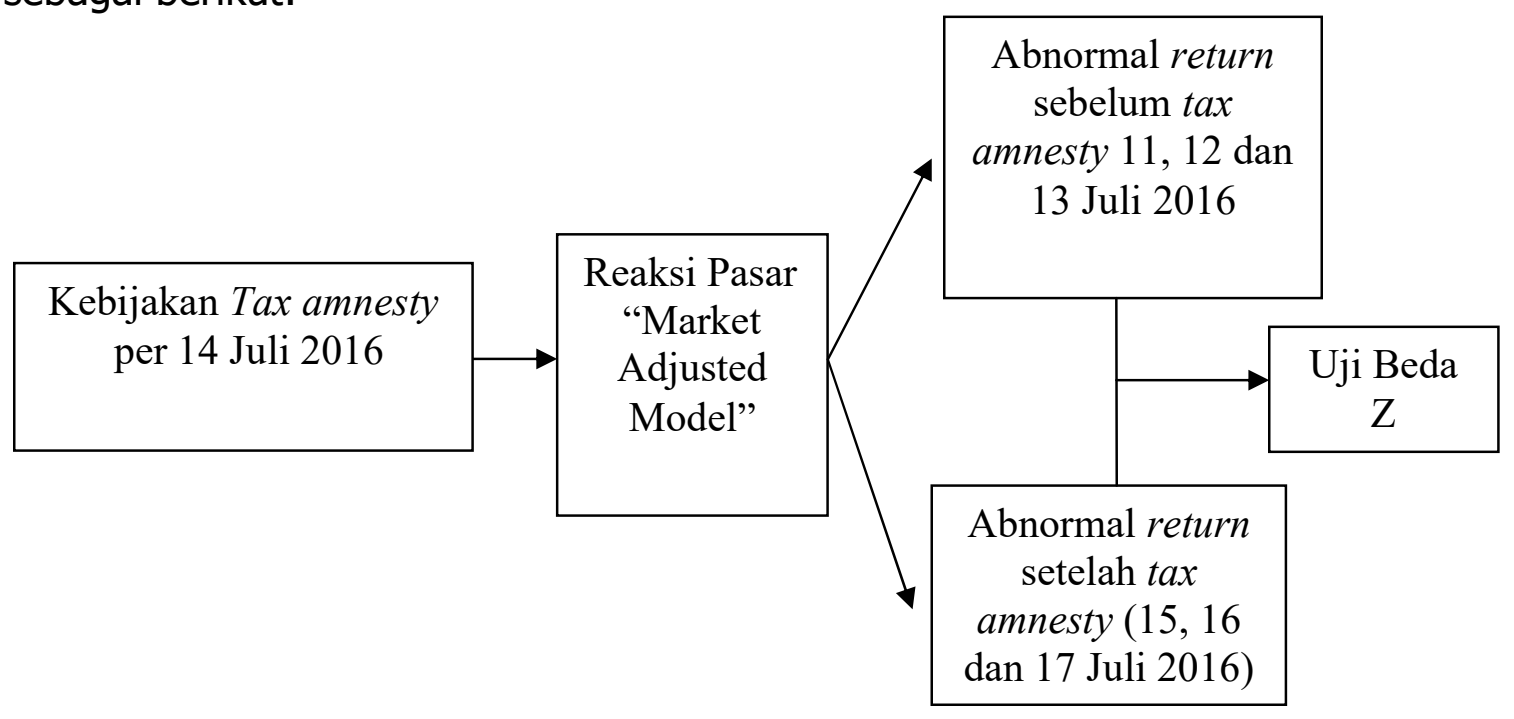

Gambar 1. Kerangka Konseptual Penelitian

\section{Pengembangan Hipotesis}

Tax amnesty bukan sebatas upaya untuk memperoleh pendapatan bagi pemerintah, tetapi juga diharapkan dapat memulangkan dana pengusaha yang ada di luar negeri. Dana tersebut diharapkan dapat diinvestasikan di Indonesia dalam berbagai bentuk portofolio, seperti saham, obligasi dan surat berharga lainnya. Hal ini yang menjadi perhatian Rasbin (2016) dalam kajiannya atas potensi dana repatriasi dan dana pembangunan dari kebijakan tax amnesty. Hasil kajian di atas memberikan perspektif positif atas kebijakan 
tax amnesty, bukan sebatas tujuan jangka pendek, tetapi tujuan jangka panjang berupa mengalirnya dana pengusaha yang ada di luar negeri.

Berdasarkan uraian tersebut, maka dirumuskan hipotesis dalam penelitian ini yaitu:

H 1: "Terdapat perbedaan yang signifikan atas reaksi pasar (abnormal return) saham-saham perusahaan pada Indeks LQ-45 yang terdaftar di BEI sebelum dan sesudah tax amnesty 14 Juli 2016".

\section{METODE PENELITIAN}

Jenis penelitian ini merupakan studi peristiwa (event study) yang menganalisis adanya reaksi pasar sebagai akibat dari terjadinya suatu peristiwa. Peristiwa yang menjadi kajian dalam penelitian ini adalah kebijakan Tax amnesty. Penelitian ini dilakukan pada perusahaan-perusahaan yang masuk dalam daftar Indeks LQ-45 periode Juli tahun 2016, dengan mengunjungi situs resmi Bursa Efek Indonesia (BEI) yaitu www.idx.co.id dan www.yahoofinance.com.

Populasi dalam penelitian ini adalah saham-saham yang masuk dalam daftar LQ-45. Metode sampling yang digunakan dalam penelitian ini menggunakan metode sensus/sampling jenuh. Metode pengumpulan data dalam penelitian ini menggunakan teknik dokumentasi. Teknik dokumentasi merupakan teknik pengumpulan data dengan melakukan pencatatan atas dokumen yang dimiliki oleh pihak lain (Siregar,2014). Dalam penelitian ini data yang dibutuhkan adalah data-data yang disiapkan oleh BEI, yang diambil melalui www.idx.co.id dan www.yahoofinance.com. Data yang dikumpulkan berupa harga saham dan data IHSG periode kajian (tanggal 11, $12,13,14,15,16$ dan 17) untuk setiap saham perusahaan yang termasuk dalam daftar LQ-45. Tanggal 11-13 ( $\mathrm{t}_{-1} /$ tanggal $13, \mathrm{t}_{-} /$tanggal 12 dan $\mathrm{t}$ 3/tanggal 11) sebagai periode pra kebijakan tax amnesty dan tanggal 15-17 $\left(\mathrm{t}_{+1} /\right.$ tanggal $15, \mathrm{t}_{-2} /$ tanggal 16 dan $\mathrm{t}_{+3} /$ tanggal 17$)$ sebagai periode pasca kebijakan tax amnesty. Adapun tanggal 14 juli $\left(\mathrm{t}_{0}\right)$ merupakan tanggal peristiwa diumumkan. Periode 11-17 Juli 2017 sebagai periode jendela (windows periods), tanpa ada periode estimasi karena perhitungan return ekspektasi menggunakan market-adjusted model. Ekspektasi return secara langsung dihitung berdasarkan return pasar (pertumbuhan IHSG).

Data yang dikumpulkan berupa harga saham dan data IHSG periode kajian (tanggal 11-17 Juli 2016). Adanya kebutuhan periode dasar untuk perhitungan return aktual ataupun return ekspektasi pada tanggal 11, maka dibutuhkan juga informasi pada tanggal 10 Juli 2016. Variabel dalam penelitian ini adalah: 
Bq. Anggun HL, Eni Indriani, \& Retno Dwi H.: Analisis Reaksi Pasar atas...

a. Reaksi pasar

Reaksi pasar adalah respon yang diberikan oleh pelaku investasi di pasar modal, yang dilihat dari kondisi perubahan harga saham secara relatif (Hartono:2016). Dalam penelitian ini reaksi pasar diproxikan dengan abnormal return, sebagai selisih dari return aktual dengan return ekspektasi.

1. Return aktual adalah perubahan relatif dari harga saham individual pada periode $t$ terhadap periode $t-1$. Perubahan dengan nilai relatif positif menunjukkan return positif atau capital gain bagi pemegang saham terkait.

2. Return ekspektasi merupakan nilai yang dijadikan sebagai pedoman atau dasar perkiraan dalam menilai saham individual, dihitung dengan menggunakan nilai relatif dari IHSG periode $t$ terhadap periode $\mathrm{t}-1$. Return ekspektasi menggunakan return pasar, sesuai dengan model yang digunakan, yaitu market-adjusted model.

Langkah awal dalam penelitian ini adalah perhitungan atas besaran yang digunakan sebagai proxi untuk mengukur abnormal return.

1. Perhitungan Return aktual

Return aktual $\left(R_{i . t}\right)$ ditentukan sebagai berikut:

$$
\frac{\left(P_{i . t}-P_{i .(t-1)}\right)}{P_{i(t-1)}} \text { (Hartono, 2016:648). }
$$

Keterangan: i adalah saham perusahaan tertentu yang tergabung dalam LQ45 , sedangkan $t$ adalah periode. $P$ adalah harga saham perusahaan secara individual. Dalam penelitian ini perhitungan return aktual dilakukan pada windows period enam hari, tiga hari sebelum pengumuman tax amnesty (11,12 dan 13 Juli 2016) dan tiga hari pasca pengumuman tax amnesty (tanggal 15,16 dan 17 Juli 2016). Hasil perhitungan ini memberikan gambaran perolehan return aktual (jika positif berarti capital gain dan jika negatif berarti capital loss).

2. Perhitungan Return Ekspektasi

Return perkiraan atau ekspektasian dalam market adjudsted model merupakan perubahan relatif dari IHSG periode $t$ dengan IHSG periode $t-$ 1. Perhitungannya sebagai berikut:

$$
E\left(R_{i . t}\right)=\frac{\left(I H S G_{j}-I H S G_{(j-1)}\right)}{I H S G_{j-1}} \text { (Hartono, 2016:653). }
$$

Periode perhitungannya sesuai dengan windows period yang telah ditentukan, yaitu periode pra pada tanggal 11-17 Juli 2016. Rumus di atas digunakan sesuai dengan penggunaan model market-ajusted model.

3. Perhitungan Abnormal return 
Perhitungan abnormal return dilakukan per saham pada windows period (tanggal 11, 12 dan 13 Juli 2016 serta 15, 16 dan 17 Juli 2016). Rumus untuk menentukannya adalah:

$$
\mathrm{RTN}_{\mathrm{it}}=\mathrm{R}_{\mathrm{i} . \mathrm{t}}-\mathrm{E}\left[\mathrm{R}_{\mathrm{i} . \mathrm{t}}\right] \quad \text { (Hartono, 2016:648). }
$$

Keterangan :

$\mathrm{RTN}_{\mathrm{i} . \mathrm{t}}=$ Return tak normal sekuritas ke-i pada periode peristiwa ke-t.

$\mathrm{R}_{\mathrm{i}, \mathrm{t}} \quad=$ Return realisasian yang terjadi untuk sekuritas ke-i pada Peristiwa ke $-\mathrm{t}$

$\mathrm{E}\left[\mathrm{R}_{\mathrm{i} . \mathrm{t}}\right]=$ Return ekspektasi sekuritas ke-i untuk periode peristiwa ke-t.

Untuk mengetahui perubahan harga saham dan perbedaan harga saham, maka diperlukan langkah perhitungan sebagai berikut:

1. Melakukan perhitungan Average Abnormal Return (AAR)

Average Abnormal Return (AAR) merupakan abnormal return dari semua jenis saham yang sedang dianalisis secara harian. AAR dapat menunjukkan reaksi paling kuat, baik positif maupun negatif dari keseluruhan jenis saham pada hari-hari tertentu selama window period.

Menguji rata-rata return tidak normal seluruh sekuritas untuk tiap-tiap hari di periode peristiwa. Rata-rata return tidak normal untuk hari ke-t dapat dihitung berdasarkan (Jogianto, 2016):

Dimana :

$$
\mathbf{A A R}_{\mathrm{t}}=\frac{\sum_{i=t}^{k} R T N i, t}{k}
$$

$\mathrm{AAR}_{\mathrm{t}}=$ Rata-rata return tidak normal (Average Abnormal Return) pada hari ke-t

RTNi,t $=$ Return tidak normal (Abnormal Return) untuk sekuritas ke-i pada hari ke-t

$\mathrm{K}=$ Jumlah Sekuritas

2. Melakukan Perhitungan Cummulative Abnormal Return (CAR)

Perhitungan terhadap Cummulative Abnormal Return (CAR) dilakukan untuk menggambarkan keseluruhan abnormal return selama periode event. Penghitungan CAR dapat dilakukan dengan rumus sebagai berikut (Jogianto, 2016):

Dimana:

$$
C A R=\sum_{i=1}^{n} A R_{i, a}
$$

CAR = Cumulative Abnormal Return

$\mathrm{AR}_{\mathrm{i}, \mathrm{a}}=$ Abnormal return untuk sekuritas ke $\mathrm{i}$ pada hari ke a sampai hari ke $\mathrm{t}$ 
Bq. Anggun HL, Eni Indriani, \& Retno Dwi H.: Analisis Reaksi Pasar atas...

3. Melakukan Perhitungan Cummulative Average Abnormal Return (CAAR)

Perhitungan terhadap Cummulative Average Abnormal Return (CAAR) dapat dilakukan dengan menggunakan average abnormal return atau cumulative abnormal return. Perhitungan CAAR dengan average abnormal return dapat dilakukan dengan rumus sebagai berikut (Jogianto,2016):

$$
C A A R=\sum_{i=1}^{n} A A R_{i a}
$$

Dimana:

CAAR $\quad=$ Cumulative Average Abnormal Return

AAR $_{\text {ia }} \quad=$ Average abnormal return saham ke-i pada hari ke-a, yaitu awal periode jendela sampai dengan hari ke-t.

Cara lain untuk mendapatkan nilai CAAR dapat menggunakan cumulative abnormal return. Perhitungan CAAR dengan menggunakan cumulative abnormal return dapat dilakukan dengan rumus sebagai berikut (Jogianto,2016):

Dimana:

$$
C A A R=\frac{\sum_{i=1}^{n} C A R_{i t}}{k}
$$

$$
\begin{array}{ll}
\text { CAAR } & =\text { Cumulative Average Abnormal Return } \\
\text { CARit } & =\text { Cumulative abnormal return sekuritas ke-I pada hari } \\
& \text { ke-t } \\
\mathrm{K} & =\text { Jumlah sekuritas. }
\end{array}
$$

Abnormal return yang akan diuji dalam penelitian ini adalah Cumulative Average Abnormal Return (CAAR). Cumulative Average Abnormal Return dapat mewakili nilai Average Abnormal Return (AAR) dan Cumulative Abnormal Return (CAR).

\section{PEMBAHASAN}

Hasil uji beda atas reaksi pasar yang diproxikan dengan abnormal return secara berpasangan pada tiga hari pra dan pasca kebijakan tax amnesty ternyata diperoleh nilai $Z$ hitung yang negatif. Pada hari pertama pra dan pasca kebijakan tax amnesty ditemukan kriteria pengujian $\mathrm{H}_{a}$ diterima pada uji arah kiri. Ada perbedaan yang nyata bersifat negatif dari kebijakan tax amnesty, terbukti bahwa uji beda antara abnormal return pasca dan pra kebijakan tax amnesty negatif. Pasar modal menerima informasi berlakunya 
tax amnesty ternyata muncul sebagai informasi negatif bagi investor. Dapat dinyatakan pada hari pertama kebijakan tax amnesty mendapatkan reaksi yang sangat negatif di pasar modal, sehingga harga saham memberikan dampak pada capital lost jika dibandingkan antara harga sebelum hari pertama dengan hari pertama setelah kebijakan tax amnesty. Hasil pengujian ini memberikan pembuktian atas hasil penelitian Rahayu (2016), bahwa kebijakan tax amnesty oleh pemerintah pada tanggal 14 Juli 2016 tidak memberikan perbedaan abnormal return saham perusahaan.

Pada hari kedua dan ketiga pra dan pasca kebijakan tax amnesty ternyata masih ada respon negatif (terbukti dengan nilai $Z$ hitung), tetapi tidak menghasilkan perbedaan yang nyata. Pada hari kedua dan ketiga reaksi negatif atas kebijakan tax amnesty mulai berkurang. Pada kondisi ini, maka peran pemerintah untuk melakukan sosialisasi atas kebijakan tax amnesty, perbaikan atau reformasi perpajakan serta yang paling urgen adalah adanya jaminan bahwa dana yang dihimpun dari wajib pajak (peserta tax amnesty) masuk dalam kas negara dan digunakan kembali untuk memberikan stimulan positif atas perekonomian makro.

Pengujian menggunakan parameter average abnormal return membuktikan bahwa terdapat perbedaan yang nyata antara reaksi pasar sebelum dan sesudah kebijakan tax amnesty, dengan kriteria reaksi yang negatif. Pemerintah harus menyadari bahwa kebijakan tax amnesty merupakan kebijakan yang tidak memberikan good news atau bersifat negatif bagi para investor. Fakta empiris ini menyimpulkan bahwa reaksi pasar lebih baik pada periode pra kebijakan tax amnesty dibandingkan dengan periode pasca kebijakan tax amnesty.

Dalam penelitian yang dilakukan, parameter yang dikaji adalah implikasi dari perilaku investor, bahwa ternyata abnormal return mengalami penurunan setelah adanya kebijakan tax amnesty.Fakta menunjukkan bahwa tujuan yang dirumuskan telah jelas, sesuai dengan ayat 2 pasal 2 UU No. 11 Tahun 2016, tetapi hal yang menjadi masalah adalah tujuan tersebut tidak bermakna positif bagi perekonomian Indonesia. Fakta juga dapat terlihat bahwa efektivitas penggunaan pendapatan negara masih belum optimal, lebih banyak untuk membayar belanja rutin (belanja pegawai), belanja hutang serta kondisi minim dan tidak terarah untuk belanja pembangunan.

Terbukti dalam penelitian ini, bahwa reaksi pasar berbeda nyata secara negatif periode pra dan pasca kebijakan tax amnesty. Informasi pemberlakuan tax amnesty oleh pemerintah tidak dapat dikelola sebagai suatu yang positif oleh para agency dalam mengelola perusahaan. Pihak yang paling tahu mengenai kondisi perusahaan (para agen dalam teori sinyal) tidak dapat menjadikan tax amnesty sebagai faktor eksternal yang menguntungkan 
perusahaan. Dalam konteks teori fundamental, bahwa kebijakan pemerintah sebagai faktor fundamental, ternyata kebijakan tax amnesty adalah faktor fundamental yang bersifat negatif yang memberikan pengaruh nyata bersifat negatif terhadap nilai perusahaan (harga saham). Dalam konteks teori stakeholder (Ghozali dan Chariri (2007) dalam Iryanie (2009), bahwa nilai perusahaan tidak dapat ditingkatkan, bahkan negatif di pasar modal sebagai implikasi kebijakan tax amnesty. Peran agency, baik berdasarkan pada teori sinyal ataupun teori stakeholder harus berupaya meminimalkan penurunan harga saham sebagai dampak dari kebijakan tax amnesty.

Kaitan informasi dipasar modal yaitu efisiensi pasar, menunjukkan bahwa pasar dalam hal ini adalah pasar efisien dalam bentuk setengah kuat, yang berarti atas adanya informasi publik berupa pengumuman kebijakan tax amnesty yang dipublikasikan dapat mencerminkan reaksi pasar dalam harga saham.

Investor dalam mengambil setiap keputusan investasi adalah selalu berusaha untuk meminimalisir berbagai risiko yang timbul, return atas saham memiliki hubungan kuat dengan resiko (risk), jika risiko tinggi maka return juga akan tinggi, begitu pula sebaliknya. Fluktuasi harga saham yang terjadi atas tiap periode karena adanya pengumuman tax amnesty dianggap sebagai risiko dalam berinvestasi. Resiko ini digolongkan sebagai risiko yang tidak sistematis (Unsystematic Risk) yang dampaknya masih bisa untuk diatasi dengan cara seperti diversifikasi portofolio.

Pemerintah dalam konteks tujuan penerapan tax amnesty yang akan menggerakkan investasi, ternyata berlawanan dengan kondisi empiris. Pemerintah dinilai belum bisa menciptakan kondisi bisnis yang bergairah. Pemerintah selama ini dianggap kurang dipercayai dalam penggunaan penerimaan dari pajak untuk pembangunan. Dapat juga dinyatakan bahwa pemerintah harus melakukan perbaikan dalam penggunaan dana penerimaan dari pajak, dengan memberikan jaminan efektivitas pembangunan sebagai stimulan perekonomian dan spesifik pada pasar modal.

\section{KESIMPULAN DAN SARAN}

\section{Kesimpulan}

Kesimpulan dalam penelitian ini adalah Secara rata-rata atas reaksi pasar yang diproxikan dengan average abnormal return, ternyata menghasilkan kriteria pengujian berbeda nyata dan negatif atas abnormal return periode pra dan pasca kebijakan tax amnesty. Abnormal return periode pasca lebih rendah dari abnormal return pasca kebijakan tax amnesy. Dalam konteks teori sinyal bahwa pengetahuan yang dimiliki agency 
mengenai kondisi internal perusahaan tidak dapat membuat informasi tax amnesty sebagai stimulan kinerja internal perusahaan. Konteks teori stakeholder menunjukkan bahwa para agency tidak dapat menjadikan informasi tax amnesty sebagai suatu yang memberikan stimulan positif bagi peningkatan nilai perusahaan. Fakta yang ada justeru menyebabkan nilai perusahaan menurun. Berdasarkan konteks teori fundamental, maka faktor kebijakan pemerintah berupa tax amnesty ini muncul sebagai informasi yang memberikan pengaruh bersifat negatif bagi agency, investor, dan mempengaruhi pasar modal.

\section{Saran}

Saran bagi peneliti selanjutnya dirasa perlu mengkaji periode (windows period) yang lebih panjang serta subyek yang lebih banyak, dan bukan saja perusahaan dalam kelompok tertentu yang telah diklasifikasi oleh pihak BEI dengan subyek dan waktu yang lebih panjang, sehingga data observasi ( $\mathrm{n}$ data panel) lebih banyak. Dapat juga menggunakan proxi reaksi pasar lainnya, tetapi yang sifatnya adalah implementasi (salah satunya volume transaksi saham).

\section{Implikasi Hasil Penelitian}

Hasil penelitian ini dapat memberikan beberapa implikasi yaitu:

Secara Teoritis penelitian ini sejalan dengan teori sinyal yang memberikan pengertian bahwa dengan adanya suatu peristiwa maka investor akan mengidentifikasikannya sebagai informasi yang memberikan sinyal yang baik (good news) ataupun sinyal yang buruk (bad news), dimana persepsi atas penilaian investor ini akan tercermin pada perubahan harga saham yang terjadi. Informasi yang terkandung atas pengumuman tax amnesty ini menunjukkan adanya perbedaan yang signifikan, sehingga investor sebaiknya dapat menyikapi dengan lebih bijak dan berhati-hati dalam mengambil keptusan investasi di pasar modal .

Secara Praktis penelitian ini memberikan implikasi bagi pemerintah untuk lebih melakukan evaluasi dalam menerapkan kebijakan, termasuk dalam kebijakan fiskal berupa tax amnesty. Kebijakan tax amnesty mendapatkan reaksi yang negatif di pasar modal (agency dan investor), sehingga menyebabkan pasar lesu, terbukti dengan harga saham yang menurun di pasca kebijakan dan selanjutnya berdampak pada abnormal return yang lebih rendah dibandingkan dengan periode pra kebijakan tax amnesty. Sangat dikhawatirkan pemerintah mendapatkan aliran kas masuk, tetapi fakta di lapangan ada pasar yang lesu. Pemerintah harus memberikan jaminan melalui perbaikan yang terus menerus atas sistem perpajakan, 
Bq. Anggun HL, Eni Indriani, \& Retno Dwi H.: Analisis Reaksi Pasar atas...

khususnya dalam menerapkan tax amnesty dan implementasi dari dana yang dihimpun harus bersifat nyata dalam memberikan stimulan bagi perekonomian nasional.

\section{DAFTAR PUSTAKA}

Andi. 2015. Belajar Cepat Analisis Statistik Parameterik dan Non Parameterik dengan SPSS. Wahana Komputer .Semarang.

Direktorat Jenderal Anggaran. 2016. Informasi APBN 2016. Direktorat Penyusunan APBN, Direktorat Jenderal Anggaran. Jakarta. Direktorat Jenderal Pajak. 2016. Amnesty Pajak. Kementerian Keuangan. Jakarta.

Direktorat Jendral Pajak. 2016. Tax Amnesty. Kementerian Keuangan Republik Indonesia.

Fahmi, I., 2014. Manajemen Keuangan Perusahaan dan Pasar Modal. Jakarta: Mitra Wacana Media.

Gunawan, A. 2016. Pengaruh Persepsi Tax Amnesty, Pertumbuhan Ekonomi dan Transformasi Kelembagaan Direktorat Jenderal Pajak Pada Penerimaan Pajak Tahun Pajak 2015 di Kantor Pelayanan Pajak Pratama Bandung Utara. Skripsi. Universitas Udayana:Fakultas Ekonomi Dan Bisnis.

Hadi, Sasana., 2004. Kegagalan Pemerintah Dalam Pembangunan. Jurnal Ekonomi 1(1): 31-38.

Hanafi, M.M., dan Halim, A., 2005. Analisis Laporan Keuangan. Yogyakarta: UPP AMP YKPN.

Hartono,J., 2016. Teori Portofolio dan Analisis Investasi. Yogyakarta: BPFE UGM.

Iryanie, E. 2009. Komitmen Stakeholder Perusahaan terhadap Kinerja SosialDan Kinerja Keuangan(Studi Empiris Pada Perusahaan yang Terdaftar di Bursa Efek Indonesia).Tesis.Universitas Dipoegoro Semarang.

Kementerian Hukum dan HAM, 2015. Naskah Akademik Rancangan Undangundang tentang Ketentuan Umum dan Tata Cara Perpajakan.Jakarta.

Kementerian Keuangan Republik Indonesia. 2013. Undang-Undang KUP Dan Peraturan Pelaksanaannya. Undang-Undang republik Indonesia Nomor 16 Tahun 2009. Direktorat Penyuluhan, Pelayanan, dan Hubungan Masyarakat.Jakarta.

M. Irfan, Islamy., 2001, Prinsip-prinsip Perumusan Kebijakan Negara, Bumi Aksara, Jakarta.

Muttaqin, Z., 2013. Tax Amnesty di Indonesia. Bandung: PT. Refika Aditama. 
Nar, M., 2015. The Effects of Behavioral Economics on Tax Amnesty. International Journal of Economics and Financial Issues. Vol. 5. No. 2.

Ngadiman dan Huslin, D., 2015. Pengaruh Sunset Policy, Tax Amnesty, dan Sanksi Pajak Terhadap Kepatuhan Wajib Pajak (Studi Empiris Di Kantor Pelayanan Pajak Pratama Jakarta Kembangan). Jurnal Akuntansi. Vol. XIX. No.2.

Rahayu,D.2016.Analisis Reaksi Pasar Modal Terhadap Kebijakan Amnesty Pajak (studi kasus pada saham-saham syariah yang masuk daftar JII periode Juni-November 2016).Tesis. Universitas Sunan Kalijaga Yogyakarta.

Rasbin. 2016. Tax Amnesty, Potensi Dana Repatriasi, dan Pembangunan di Indonesia. Majalah Info Singkat Ekonomi Dan Kebijakan Publik 8(8).

Undang-Undang Republik Indonesia Nomor 8 Tahun 1995 Pasar Modal.

Undang-Undang Republik Indonesia Nomor 11 Tahun 2016 Pengampunan

Pajak 1Juli 2016. Lembaran Negara Republik Indonesia Tahun 2016 Nomor 131. Jakarta.

Waluyo, 2014. Perpajakan di Indonesia. Jakarta: Salemba Empat.

www.idx.co.id diakses tanggal 01 Januari 2017 jam 22:23. 